\title{
OPEN Author Correction: Finding Plastic Patches in Coastal Waters using Optical Satellite Data
}

\section{Lauren Biermann, Daniel Clewley, Victor Martinez-Vicente \& Konstantinos Topouzelis}

Correction to: Scientific Reports https://doi.org/10.1038/s41598-020-62298-Z, published online 23 April 2020

The original version of this Article contained errors.

All instances of 'San Juan Islands' now read 'Gulf Islands'.

Additionally, as a result of clerical error the wrong sign was used in the definition of $\mathrm{R}_{\mathrm{rs}, \mathrm{NIR}}^{\prime}$ in Eq. (1), where the first instance of a minus should have been a plus:

$$
\begin{aligned}
& F D I=R_{r s, N I R}-R_{r s, N I R}^{\prime} \\
& R_{r s, N I R}^{\prime}=R_{r s, R E 2}-\left(R_{r s, S W I R 1}-R_{r s, R E 2}\right) \times \frac{\left(\lambda_{\text {NIR }}-\lambda_{R E D}\right)}{\left(\lambda_{S W I R 1}-\lambda_{R E D}\right)} \times 10
\end{aligned}
$$

now reads:

$$
\begin{aligned}
& F D I=R_{r s, N I R}-R_{r s, N I R}^{\prime} \\
& R_{r s, N I R}^{\prime}=R_{r s, R E 2}+\left(R_{r s, S W I R 1}-R_{r s, R E 2}\right) \times \frac{\left(\lambda_{N I R}-\lambda_{R E D}\right)}{\left(\lambda_{S W I R 1}-\lambda_{R E D}\right)} \times 10
\end{aligned}
$$

This has now been corrected in both PDF and HTML version of the Article.

\begin{abstract}
(c) (i) Open Access This article is licensed under a Creative Commons Attribution 4.0 International License, which permits use, sharing, adaptation, distribution and reproduction in any medium or format, as long as you give appropriate credit to the original author(s) and the source, provide a link to the Creative Commons license, and indicate if changes were made. The images or other third party material in this article are included in the article's Creative Commons license, unless indicated otherwise in a credit line to the material. If material is not included in the article's Creative Commons license and your intended use is not permitted by statutory regulation or exceeds the permitted use, you will need to obtain permission directly from the copyright holder. To view a copy of this license, visit http://creativecommons.org/licenses/by/4.0/.
\end{abstract}

(C) The Author(s) 2020 